\title{
14. The Adenosinetriphosphatase Activity of Myosin Preparations
}

\author{
By Dorothy Moyle Needham, From the Biochemical Laboratory, Cambridge
}

(Received 6 February 1942)

It has been known for many years that muscle contraction is accompanied by appearance of equivalent amounts of inorganic phosphate and free creatine, creatinephosphate disappearing. Until the work of Lohmann [1934] using muscle extract, this process was regarded as an enzymic hydrolysis of creatinephosphate, going on with liberation of energy. But Lohmann showed that the breakdown of creatinephosphate is a composite process, requiring the presence in the extract of adenylic acid and adenosinetriphosphatase:

(I) 2 creatinephosphate + adenylic acid $\rightarrow 2$ creatine + adenosinetriphosphate

$$
\text { adenosinetriphosphate } \rightarrow \text { adenylic acid }+2 \mathrm{H}_{3} \mathrm{PO}_{4} \text {. }
$$

Thus free energy of creatinephosphate breakdown is used for resynthesis of adenosinetriphosphate (ATP). Further work in several laboratories has since shown that the energy-rich phosphorylated intermediates in carbohydrate breakdown, phosphopyruvic acid [Ostern et al. 1935; Needham \& van Heyningen, 1935; Meyerhof \& Lehmann, 1935; Lehmann, 1935] and diphosphoglyceric acid [Warburg \& Christian, 1939] are similarly used in the muscle to rebuild ATP (see Fig. 1). The central importance of ATP breakdown

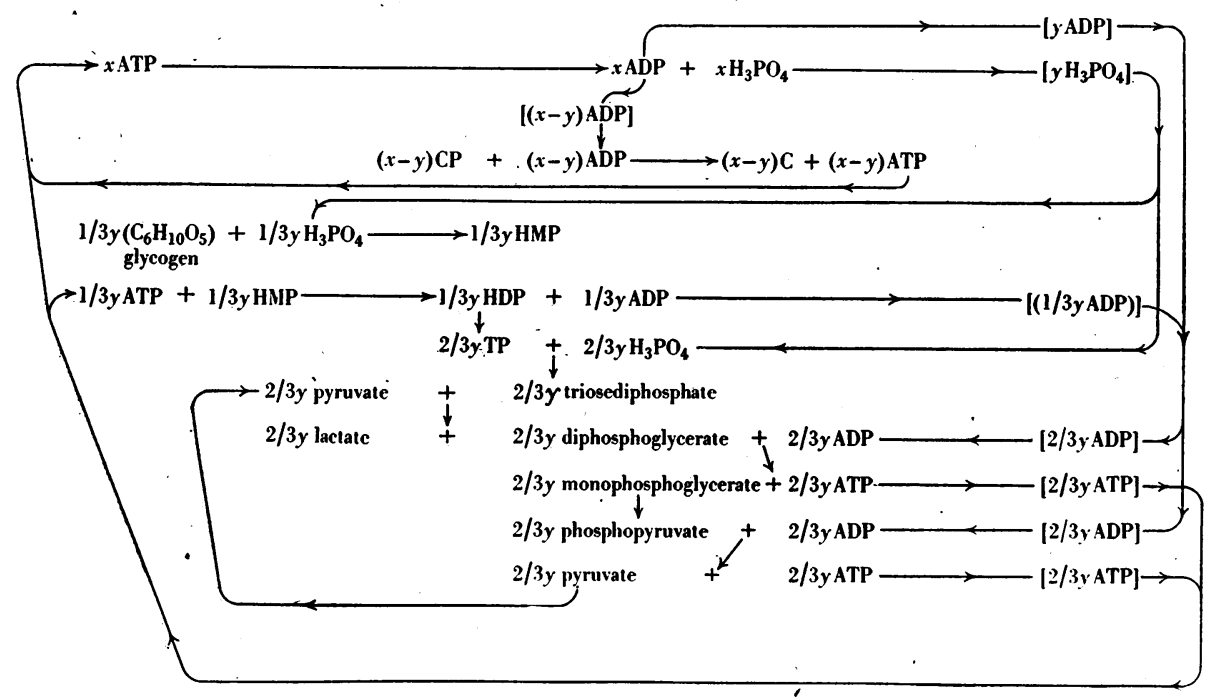

Fig. 1. Diagram showing chemical changes in muscle contraction. ATP=adenosinetriphosphate; ADP = adenosinediphosphate; $\mathbf{C P}=$ creatinephosphate; $C=$ creatine; HMP = hexosemonophosphate; HDP = hexosediphosphate; TP = triosephosphate.

as (1) the only reaction going on with liberation of energy available for the process of contraction, (2) the first chemical reaction demonstrable upon stimulation, thus becomes obvious [see Needham, 1937; 1938].

The correctness of the view that the inorganic phosphate formed on contraction has its origin in ATP is borne out by the fact that muscle brei shows high phosphatase activity with ATP as substrate, two phosphate groups being split off, but that other phosphatases are very feeble or absent.

Biochem. 1942, 36 
Lohmann [1935, 1, 2] showed that in the formation of adenylic acid from ATP, adenosinediphosphate (ADP) occurs as an intermediate, and indications have accumulated that probably in the muscle itself reaction (I) runs

$$
\begin{aligned}
\text { Creatinephosphate }+\mathrm{ADP} & \rightarrow \text { creatine }+\mathrm{ATP} \\
\mathrm{ATP} & \rightarrow \mathrm{ADP}+\mathrm{H}_{3} \mathrm{PO}_{4} \text { [see Lehmann, 1936], }
\end{aligned}
$$

dephosphorylation of ATP perhaps usually not proceeding past the loss of one phosphate group.

The important work of Engelhardt \& Liubimova [1939] and of Liubimova \& Engelhardt [1939] showed that the adenosinetriphosphatase activity of muscle is associated with the myosin fraction of the muscle proteins. After purification of the myosin by repeated reprecipitation, the protein was still just as active in splitting off one phosphate group from ATP, but had lost entirely the power, shown by the brei or by once-precipitated myosin, of converting ADP into adenylic acid [Liubimova \& Pevsner, 1941; Bailey, 1942].

The question of the identity of adenosinetriphosphatase and myosin has been considered by Liubimova \& Engelhardt [1939] and by Bailey [1942]. If the protein myosin, of which the contractile fibrils are composed, can indeed interact enzymically with the substance ATP, whose breakdown provides the energy of contraction, then the significance of this fact in the mechanism of contraction must be very great. The mode of interaction between the myosin and the ATP, and the ways in which this interaction might affect the length of the fibrils, has been considered by Engelhardt \& Liubimova [1939], Kalckar [1941; 1942], Needham et al. [1941] and Bailey [1942].

Most of the experiments described below were done in 1939 and early 1940. It was impossible to continue them, but the work has been continued and extended by Dr K. Bailey.

\section{Experimental methods}

(1) Preparation of myosin. The myosin was made from rabbit muscle and from the muscle of Rana esculenta, usually by the method of Greenstein \& Edsall [1940], sometimes by that of Weber \& Meyer [1933]. On one occasion, a $\mathrm{LiCl}$ extract of rabbit muscle was made [Smith, 1934], and the myosin prepared from this had the same degree of activity as the myosin made from muscle of the same animal by Greenstein \& Edsall's method. The myosin was usually precipitated twice. The myosin content was assessed by estimating the protein $\mathrm{N}$.

(2) Preparation of ATP. The ATP was prepared as the Ba salt by the method in use in Prof. Parnas's laboratory at Lwów: I am indebted to Dr C. Lutwak-Mann for details [see also Lohmann \& Schuster, 1935].

A rabbit is killed, bled and skinned. The carcass is cooled in ice and then the muscle is rapidly removed. It is kept cold and minced through a cooled mincer. It is then mixed with an equal weight of ice-cold $10 \%$ trichloroacetic acid and well stirred. After a few minutes the mixture is strained through muslin, the residue is squeezed as dry as possible and again extracted with an equal weight of $4 \%$ trichloroacetic acid. After straining again, the united filtrates are centrifuged. The supernatant liquid is brought with $40 \%$ $\mathrm{NaOH}$ to $p \mathrm{H} 6 \cdot 8$, and $50 \% \mathrm{Ba}$ acetate is added until no more precipitate is formed. After 1-2 $\mathrm{hr}$. at $0^{\circ}$, when the precipitate (Ba salts of ATP and-inorganic phosphate) has settled, the supernatant liquid is decanted off, the precipitate is centrifuged down and washed with water. The precipitate is treated with $0 \cdot 2 \mathrm{~N} \mathrm{HNO}_{3}$ until the reaction is faintly blue to Congo-red paper and the small amount of insoluble material is rejected. The ATP is then precipitated as the $\mathrm{Hg}$ salt by means of Lohmann's reagent $\left(100 \mathrm{~g}\right.$. $\mathrm{HgNO}_{3}, 8 \mathrm{H}_{2} \mathrm{O}$ dissolved in a mixture of $25 \mathrm{ml} . \mathrm{HNO}_{3}$, sp. gr. 1.4, and $25 \mathrm{ml}$. water [Lohmann, 1931]) added at $0^{\circ}$, about $3-5 \mathrm{ml}$. of the reagent being needed per $\mathrm{kg}$. of muscle; after precipitation the mixture is left at $0^{\circ}$ for $15 \mathrm{~min}$. and then spun. The precipitate is suspended in a small 
volume of water made faintly acid with $\mathrm{HNO}_{3}$, and the $\mathrm{Hg}$ is removed by $\mathrm{H}_{2} \mathrm{~S}$ and filtering. $\mathrm{H}_{2} \mathrm{~S}$ is removed from the filtrate by aeration, and the reaction is brought to $p \mathrm{H} 6 \cdot 8$ with dilute $\mathrm{NaOH}$. $25 \% \mathrm{Ba}$ acetate is added until precipitation is just complete, excess being avoided. The precipitate of Ba salt is filtered off on a small Büchner funnel; it is washed well with $1 \% \mathrm{Ba}$ acetate, then with $50 \%, 75 \%$ and $97 \%$ alcohol and finally with ether. For use in the experiments, Ba was removed by dissolving the salt in the minimum amount of $\mathrm{N} \mathrm{HCl}$, diluting and adding sat. $\mathrm{Na}_{2} \mathrm{SO}_{4}$ solution, avoiding excess, until no further precipitate was obtained. The $\mathrm{BaSO}_{4}$ precipitate was spun off and washed, the combined supernatant liquids were neutralized and made up to the required volume.

Two phosphate groups of the ATP constitute the pyrophosphate-P, and are hydrolysable by $N$ acid in 7 min. at $100^{\circ}$ (' $7^{\prime} \mathrm{P}^{\prime}$ ').

(3) Method of testing the enzyme activity. The myosin gel, after precipitating for the second time and centrifuging down, was suitably diluted with distilled water and carefully mixed to give a uniform suspension. $1 \mathrm{ml}$. of this suspension was pipetted into each of a series of test-tubes and $0.5 \mathrm{ml}$. of the ATP solution was added. This contained about $0.3 \mathrm{mg} .7^{\prime} \mathrm{P} / \mathrm{ml}$. The $p \mathrm{H}$ was adjusted by means of $\mathrm{NaHCO}_{3}$ solution, as in the experiments of Liubimova \& Engelhardt [1939], $0 \cdot 1 \mathrm{ml}$. of the required concentration being added. In some of the later experiments, $\mathrm{NaHCO}_{3}-\mathrm{Na}_{2} \mathrm{CO}_{3}$ buffer, as recommended by Bailey [1942], or Michaelis veronal buffer was used. $\mathrm{MgCl}_{2}$ and $\mathrm{CaCl}_{2}, 0.05 \mathrm{ml}$. of a $0 \cdot 1 M$ solution, were used as activators; the metal was thus present in amount approximately equivalent to the pyro-P. The contents of one tube were precipitated at once by adding $1.5 \mathrm{ml}$. of $10 \%$ trichloroacetic acid; the others were incubated at $37^{\circ}$ for varying lengths of time before addition of trichloroacetic acid. The myosin clot was filtered off, the tubes and filter were washed with $4 \%$ trichloroacetic acid, and the inorganic $P$ was estimated in the filtrate by Fiske \& Subarrow's method.

\section{Results}

Distribution of adenosinetriphosphatase activity between aqueous extract of muscle and muscle residue. $5 \mathrm{~g}$. of muscle were ground very thoroughly with sand and $\mathbf{7 \cdot 5} \mathrm{ml}$. dis tilled water. The brei was allowed to stand at room temperature for $4 \mathrm{hr}$. in order that processes leading to resynthesis of ATP (and thus likely to obscure adenosinetriphosphatase activity) might be concluded. After this time, about $20 \mathrm{ml}$. more water were added; the whole was dialysed for $1.5 \mathrm{hr}$. against running water, strained through muslin and centrifuged. The extract was made up to $50 \mathrm{ml}$; the residue was ground with more water and also made up to $50 \mathrm{ml}$. Tests showed that in $5 \mathrm{~min} .0 .5 \mathrm{ml}$. of the extract split off $0.004 \mathrm{mg}$. pyro-P, while $0.5 \mathrm{ml}$. of the residue suspension split off $0.043 \mathrm{mg}$. pyro-P; i.e. the activity of the water-soluble material in a given quantity of muscle is less than $10 \%$ of that of the water-insoluble residue.

Adenosinetriphosphatase activity of myosin preparations. In the experiments with myosin from rabbit muscle it was found that $(a)$ only one phosphate group was split off; or (b) one group was rapidly split off, and that thereafter a very slow liberation of phosphate continued. Two typical experiments are shown in Fig. 2. In the case of frog muscle, some splitting off of the second group was always observed (Fig. 3).

Activation by $\mathrm{Mg}^{++}$and $\mathrm{Ca}^{++}$. The effect of $\mathrm{Mg}^{++}$upon the rate of dephosphorylation was first tried, as this ion is known to activate many phosphate transfer reactions in which ATP is concerned. Later, after the appearance of the paper of Liubimova \& Engelhardt [1939], from which it seemed likely that $\mathrm{Ca}^{++}$also must be able to serve as an activator, the effect of $\mathrm{Ca}^{++}$was also tried (Table 1 ). These results, with two different preparations of rabbit myosin, illustrated the fact that about 30-90\% activation of inorganic $\mathrm{P}$ formation is obtained by adding $\mathrm{Mg}$ ions, and that under these conditions $\mathrm{Ca}$ ions have a similar effect. 
When a much more alkaline medium was used, as in the experiments of Liubimova \& Engelhardt, it was found that the effect of $\mathrm{Ca}$ ions is much greater, that of $\mathrm{Mg}$ ions much less (Table 2).

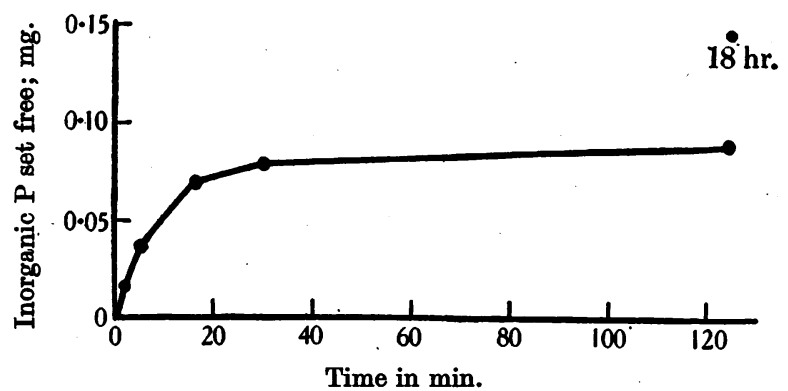

Fig. 2. Adenosinetriphosphatase activity of twice-precipitated rabbit myosin. Myosin suspension $1.85 \mathrm{mg}$. N/ml.; pH 7. ATP (0.15 mg. 7' P) added.

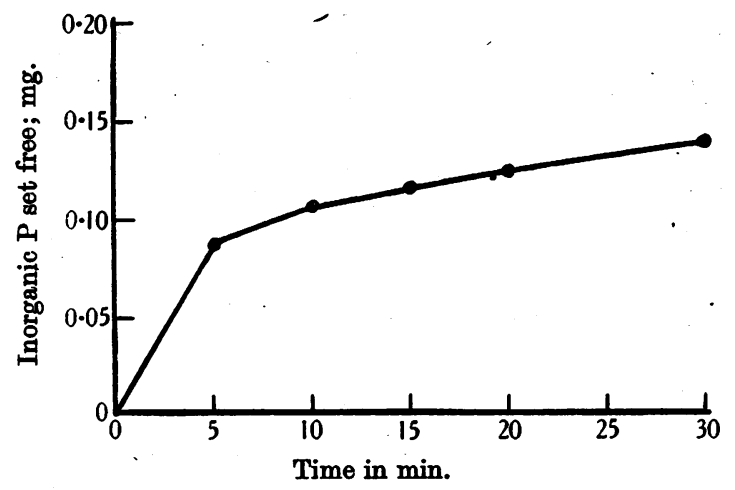

Fig. 3. Adenosinetriphosphatase activity of twice-precipitated frog myosin. Myosin suspension 0.34 mg. N/ml.; $p$ H 7.5. ATP (0.15 mg. 7' P) added.

\section{Table 1}

The reaction mixture contáined $1 \mathrm{ml}$. myosin suspension (1.5 mg. protein) $0.5 \mathrm{ml}$. ATP (0.3 mg. $\left.7^{\prime} \mathrm{P}\right)$ and $0.1 \mathrm{ml} .1 \% \mathrm{NaHCO}_{3}$.

$$
\text { Phosphate set free (mg. P) }
$$

\begin{tabular}{|c|c|c|}
\hline No activator & $\underset{\mathrm{MgCl}_{2}}{+0.05 \mathrm{ml} .0 .1}$ & $\underset{\mathrm{CaCl}_{2}}{+0.05 \mathrm{ml}^{0}} \mathbf{M}$ \\
\hline $\begin{array}{l}0.062 \\
0.017\end{array}$ & $\begin{array}{l}0.082 \\
0.033\end{array}$ & $\overline{0.033}$ \\
\hline
\end{tabular}

Table 2

The reaction mixture contained $1 \mathrm{ml}$. myosin suspension (2.4 mg. protein) and 0.5 ml. ATP (0.3 mg. $\left.7^{\prime} \mathrm{P}\right)$.

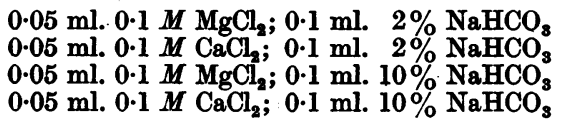

$0.05 \mathrm{ml} 0.1 \mathrm{M}$ $0.05 \mathrm{ml} .0 .1 \mathrm{M} \mathrm{MgCl} ; 0.1 \mathrm{ml} .10 \% \mathrm{NaHCO}_{3}$ $0.05 \mathrm{ml} .0 .1 \mathrm{M} \mathrm{CaCl}_{2} ; 0.1 \mathrm{ml} .10 \% \mathrm{NaHCO}_{3}$

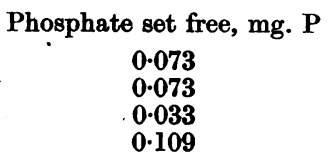

From the later experiments of Bailey, it is clear that Ca ions have a much greater effect than any other on adenosinetriphosphatase. It is likely that in the above experiments, where the protein concentration was relatively high, that enough Ca ions were present in the myosin suspension itself to activate fairly well at the low $p H$, but not at the high $p H$, where probably decreased Ca solubility has an effect. 
Since the experiments of Bailey were all carried out between $p \mathrm{H} 8$ and 9 , and since the $p \mathrm{H}$ curve of Liubimova \& Engelhardt, between $p \mathrm{H} \mathrm{7.4}$ and 9, was determined for Ca activation only, it seemed worth while to see whether with thrice-precipitated myosin and low myosin concentration (i.e. using enzyme-as free as possible from $\mathrm{Ca}^{++}$) $\mathrm{Mg}^{++}$might activate at lower $p \mathrm{H}$ in a manner comparable with $\mathrm{Ca}^{++}$. The following experiment shows that this is not the case. Veronal buffer was used and since this is a weaker buffer than bicarbonate a larger volume had to be used (Table 3).

Table 3

The reaction mixture contained $2.5 \mathrm{ml}$. of a myosin suspension (about $1 \mathrm{mg}$. protein) in $M / 35$ veronal buffer, $p \mathrm{H} \mathrm{7 \cdot 4}$, and $0.5 \mathrm{ml}$. ATP $\left(0 \cdot 2 \mathrm{mg} .7^{\prime} \mathrm{P}\right)$.

$\begin{array}{ccc}\text { Addition } & \text { Time (min.) } & \text { Phosphate set free, mg. P } \\ 0.05 \mathrm{ml} .0 \cdot 1 \mathrm{M} \mathrm{MgCl} & 5 & \text { Trace } \\ & 10 & 0.01 \\ & 45 & 0.05 \\ 0.05 \mathrm{ml} .0 .1 \mathrm{M} \mathrm{CaCl}_{2} & 5 & 0.081 \\ & 10 & 0.093 \\ & 45 & 0.097\end{array}$

Effect of iodoacetate and of $\mathrm{NH}_{4}$ salts. It has been shown that myosin in the undenatured state contains - SH groups, and that these can react with iodoacetate; they also disappear upon treatmént with $\mathrm{NH}_{4}$ salts [see e.g. Mirsky, 1936; Greenstein \& Edsall, 1940]. To see if the presence of these $\longrightarrow$ SH groups is essential for adenosinetriphosphatase activity, the following experiments were made.

(a) The reaction between $-\mathrm{SH}$ compounds and iodoacetate is slow, and the myosin must therefore be treated with the iodoacetate for some time before the substrate is added. $1 \mathrm{ml}$. samples of myosin (containing about $1 \mathrm{mg}$. protein) were incubated with $M / 300$ iodoacetate for $15 \mathrm{~min}$. at $37^{\circ}$; substrate, buffer and activator were then added, and the activity was compared with that of myosin similarly incubated without iodoacetate. It was found, however, that practically all activity had been lost in both cases; this inactivation by warming in absence of substrate (especially if the protein concentration is very low, as here) had been observed by Liubimova \& Engelhardt. The treatment with iodoacetate was therefore carried out at room temperature and in a higher protein concentration.

$10 \mathrm{ml}$. of myosin gel (containing about $10 \mathrm{mg}$. protein per ml.) were treated with $1 \mathrm{ml}$. $M / 30$ iodoacetate. Portions were removed at intervals for the nitroprusside test; this was still faintly positive after $1 \mathrm{hr}$., but completely negative after $2 \mathrm{hr} .1 \mathrm{ml}$.

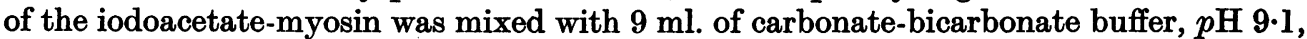
final concentration $0 \cdot 2 \%$, and the activity was compared with that of a sample of myosin which had been similarly treated, but to which water was added instead of iodoacetate (Table 4). There is thus no inhibition; experiments with $M / 300$ iodoacetamide gave a similar result.

\section{Table 4}

\begin{tabular}{clc} 
Exp. & \multicolumn{1}{c}{ Conditions } & Phosphate set free, mg. P \\
1 & Normal myosin, in 7 min. & 0.079 \\
& Iodoacetate myosin, in 7 min. & 0.077 \\
2 & Normal myosin, in 5 min. & 0.041 \\
& Iodoacetate myosin, in 5 min. & 0.042
\end{tabular}

(b) $10 \mathrm{ml}$. of myosin gel were treated with $\mathrm{NH}_{4} \mathrm{Cl}$ to give a final concentration of $2 \mathrm{~N}$. The sol was dialysed with frequent changes of water for some hours, and the precipitated myosin was spun down. The activity was compared before and after this treatment (Table 5). Here again there is no inactivation. That the $-\mathrm{SH}$ groups are inessential is 
also shown by the fact that the enzymic activity persists in glycine buffer [Bailey, 1942] although Greenstein \& Edsall [1940] found that treatment with glycine abolished the nitroprusside reaction.

\section{Table 5}

$\begin{array}{lc} & \text { Phosphate set free, mg. } \mathrm{P} \text { per mg. } \mathrm{N} \text { in } 10 \mathrm{~min} . \\ \text { Before } \mathrm{NH}_{4} \mathrm{Cl} \text { treatment } & 0.032 \\ \text { After } \mathrm{NH}_{4} \mathrm{Cl} \text { treatment } & 0.040\end{array}$

Specificity of the enzymic activity of myosin. (a) It has been conclusively shown by Liubimova \& Engelhardt [1941] and by Bailey [1942] that myosin has no adenosinediphosphatase activity; Bailey also showed that it does not hydrolyse inorganic pyrophosphate, although muscle brei does. In the present work its specificity was further tested upon $\alpha$-glycerophosphate and hexosediphosphate. The latter is of special interest since it seems to be the only metabolite besides ATP to be directly dephosphorylated at all readily by muscle [see Pillai, 1938]. Myosin precipitated three times was used, and was tested at $p H \mathbf{9 \cdot 1}$ (carbonate-bicarbonate buffer) and $p H$ 6.1 (veronal buffer), the substrate concentration being $M / 75$. Activation was tried with both $\mathrm{Mg}^{++}$and $\mathrm{Ca}^{++}$, but even in the presence of $\mathrm{Mg}^{++}$not more than 1-2\% of the phosphate of $\alpha$-glycerophosphate, or $3-4 \%$ of that of hexosediphosphate, was hydrolysed in $3 \mathrm{hr}$. at $37^{\circ}$.

(b) Although myosin so readily catalyses the transfer of phosphate from ATP to water, it has no action in bringing about transfer of phosphate from ATP to fructose-6-phosphate (Neuberg ester). This was shown in the following experiments, carried out both at $p H$ 9.1 and $p H 7 \cdot 4$ (Table 6 ). In another experiment the possibility of transesterification

Table 6

The reaction mixture contained $1 \mathrm{ml}$. of myosin suspension (about $1 \mathrm{mg}$. protein) in carbonate-bicarbonate

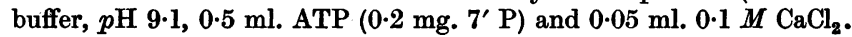

Addition
$\begin{aligned} & 0 \cdot 3 \mathrm{ml} . \mathrm{H}_{2} \mathrm{O} \\ & 0.3 \mathrm{ml} . \text { Neuberg ester }(0 \cdot 2 \mathrm{mg} . \mathrm{P})\end{aligned}$

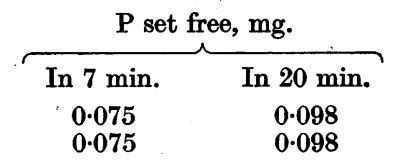

at $p \mathrm{H} \mathrm{7.4} \mathrm{in} \mathrm{presence} \mathrm{of} \mathrm{Mg}^{++}$was tested. In this case the $\mathrm{P}$ hydrolysable in $10 \mathrm{~min}$. in $N \mathrm{HCl}$ at $100^{\circ}$ was also estimated : in this hydrolysis time, two phosphate groups are split off from ATP, about $7 \%$ of the $\mathrm{P}$ of fructose- 6 -phosphate and about $37 \%$ of the hexosediphosphate-P. If now some phosphate were transferred from ATP to the Neuberg ester, with formation of hexosediphosphate, there would be a decrease in the amount of $\mathbf{P}$ hydrolysable in $10 \mathrm{~min}$. It can be calculated that if only $10 \%$ of the pyrophosphate-P of ATP were thus transferred, the decrease would amount to $7 \%$, which is well outside the experimental error (Table 7).

Table 7

The reaction mixture contained $1 \mathrm{ml}$. myosin suspension ( $1 \mathrm{mg}$. protein) in water, $0.5 \mathrm{ml}$. ÁTP, $p H$ adjusted to $7.4\left(0.22 \mathrm{mg} .7^{\prime} \mathrm{P}\right)$ and $0.05 \mathrm{ml} .0 \cdot 1 \mathrm{M} \mathrm{MgCl}_{2}$. $30 \mathrm{~min}$. at $37^{\circ}$.

\section{Addition}

$+0 \cdot 3 \mathrm{ml}$. Neuberg ester (containing $0 \cdot 2 \mathrm{mg} . \mathrm{P}$ )

$\begin{array}{cc}\text { Inorg. P } & 10^{\prime} \mathrm{P} \\ 0.026 & 0 \cdot 207 \\ 0.027 & 0.206\end{array}$

(A separate test with this myosin showed that with $\mathrm{Ca}$ activation it had the usual high adenosinetri-

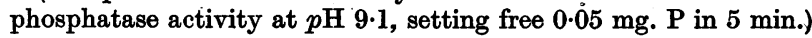

Thus just as much $\mathbf{P}$ is liberated as inorganic $\mathbf{P}$ in the presence as in the absence of Neuberg ester, and there is no indication of any hexosediphosphate formation from this ester. This result is in harmony with the finding by Sakov [1941] of an enzyme in aqueous extract of muscle which brings about phosphorylation of Neuberg ester by ATP. 


\section{Discussion}

The diagram (Fig. 1) is an attempt to summarize the chemical events during the actual stimulation period under anaerobic conditions. Hydrolysis of ATP is presented as the essential reaction supplying free energy to the contracting fibrils. The resynthesis of part of this ATP (an unknown proportion) by reaction of the ADP with creatinephosphate is shown, and the resynthesis of the rest by means of phosphorylated carbohydrate derivatives. The diagram makes clear $(a)$ how the ATP concentration is maintained constant in spite of its continual breakdown; $(b)$ how the free phosphate and free creatine formed come to be equivalent to the creatinephosphate disappearing, although not formed from it by direct hydrolysis.

When glycogen is phosphorylated by inorganic phosphate in muscle extract, the first product is the Cori ester, glucose-1-phosphate, and this is transformed into the Robison ester, glucose-6-phosphate, which is in equilibrium with fructose-6-phosphate. It is the last, the Neuberg ester which is phosphorylated by ATP to give fructosediphosphate, the Harden \& Young ester.

It should be noticed that the reaction between ATP and Neuberg ester to form hexosediphosphate is accompanied by about the same large heat output as accompanies the hydrolysis of ATP, and it seems likely that a similar amount of free energy may be produced in the two reactions. Nevertheless, as the transfer of phosphate to the Neuberg ester is catalysed by a soluble enzyme, and not by the myosin fraction, it seems unlikely that this energy would be available to the fibrils. It would form part of the waste heat which always accompanies contraction. The diagram shows, however, that during anaerobic stimulation, a relatively small part of the ATP is broken down by transesterification, much the greater part by hydrolysis under the influence of adenosinetriphosphatase.

\section{SUMMARY}

1. The finding of Engelhardt \& Liubimova was confirmed that myosin preparations have adenosinetriphosphatase activity, splitting off one phosphate group rapidly, the other very slowly or not at all. More than $90 \%$ of the adenosinetriphosphatase activity of muscle is to be found in the washed brei, less than $10 \%$ in the aqueous muscle extract.

2. Abolition of the - $\mathrm{SH}$ groups of myosin has no effect on the adenosinetriphosphatase activity. .

3. Myosin preparations show no $\alpha$-glycerophosphatase or hexosediphosphatase activity, either at $p \mathrm{H} 9 \cdot 1$ or $p \mathrm{H} 6 \cdot 0$; nor have they any power to transfer phosphate from ATP to fructose-6-phosphate.

The author is greatly indebted to Dr E. C. Bate Smith and Dr K. Bailey for much helpful discussion. Her thanks are due to Dr H. Lehmann for providing the Neuberg ester and to Dr Bate Smith for providing some of the earlier myosin preparations.

\section{REFERENCES}

Bailey, K. [1942]. Biochem. J. 36, 121.

Engelhardt, V. A. \& Liubimova, M. N. [1939]. Nature, Lond., 144, 668.

Fiske, C. H. \& Subarrow, Y. [1925]. J. biol. Chem. 66, 375.

Greenstein, J. P. \& Edsall, J. T. [1940]. J. biol. Chem. 133, 397.

Kalckar, H. [1941]. Chem. Rev. 28, 71 .

- [1942]. Biol. Rev. 17, 28.

Lehmann, H. [1935]. Biochem. Z. 281, 271.

[1936]. Biochem. Z. 286, 336.

Liubimova, M. N. \& Engelhardt, V. A. [1939]. Biochemia, 4, 716.

Liubimova, M. N. \& Pevsner, D. [1941]. Biochemia, 6, 178. 
Lohmann, K. [1931]. Biochem. Z. 233, 460.

[1934]. Biochem. Z. 271, 264.

- $[1935,1]$. Biochem. Z. 282, 109.

$[1935,2]$. Z. angew. Chem. 48, 165.

Lohmann, K. \& Schuster, P. [1935]. Biochem. Z. 282, 104.

Mejerhof, O. \& Lehmann, H. [1935]. Naturwissenschaften, 21, 337.

Meyerhof, O., Schulz, W. \& Schuster, P. [1937]. Biochem. Z. 293, 309.

Mirsky, A. E. [1936]. J. gen. Physiol. 19, 559.

Needham, D. M. [1937]. Article in Perspectives in Biochemistry. Cambridge University Press. [1938]. Enzymologia, 5, 158.

Needham, D. M. \& van Heyningen, W. E. [1935]. Biochem. J. 29, 2040.

Needham, D. M. \& Pillai, R. K. [1937]. Biochem. J. 31, 1837.

Needham, J., Shen, S. C., Needham, D. M. \& Lawrence, A. S. C. [1941]. Nature, Lond., $147,766$.

Ostern, P., Guthke, J. A. \& Terszakovec, J. [1935]. Hoppe-Seyl. Z. 243, 9.

Pillai, R. K. [1938]. Biochem. J. 32, 1087.

Sakov, N. E. [1941]. Biochemia, 6, 163.

Smith, E. C. [1934]. J. Soc. chem. Ind. Lond., 103, 351 T.

Warburg, O. \& Christian, W. [1939]. Biochem. Z. 303, 40.

Weber, H. H. \& Meyer, K. [1933]. . Biochem. Z. 266, 151. 